Indonesian Journal of EFL and Linguistics

Vol. 5 No. 2, 2020

eISSN: 2503-4197, pISSN: 2527-5070

www. indonesian-efl-journal.org

\title{
Phonology and Online Media Used in Enhancing Listening Skill
}

\author{
Dwi Astuti Wahyu Nurhayati \\ State Islamic Institute of Tulungagung, Indonesia \\ e-mail: dwiastuti@iain-tulungagung.ac.id; dwiastuti507@gmail.com
}

\begin{abstract}
:
This study examines how phonology and online media used to enhance students' listening skill. The data were collected for 5 months starting from April to August 2020 in Islamic State Institute of Tulungagung (IAIN Tulungagung). The data were collected through questionnaire and interview. It involves college students who study and major English and have the relevant information about the research theme. It consist of 196 students of $3 \mathrm{rd}$ semester in IAIN Tulungagung. The finding reveals that there are some perspectives of students about the use of phonology and online media to enhance listening skill such as: the importance of online learning English media, online learning English media towards students' attitudes in learning, the effect of online learning English media towards inferential listening, and media enhancing inferential listening skill. It was also gained students' responses towards phonology used to enhance listening skill.
\end{abstract}

Keywords: listening skill, online media, phonology

\section{INTRODUCTION}

As the most used language, English has always been studied by public from countries all around the world. It cannot be denied that the users of the language are within English countries as well as the outside. With the enormous development and vast globalization, English is required to be major as it has spread and dominated inevery sectors as in economic, industry, health, education, and entertainment. As time goes by, with the development of science and technology, people compete to learn English. 
Regarding to that issue, most countries provide education on English language so as to create good state management and competent citizens by comprehending English.

In English, there are four major skills to be mastered, those are speaking, writing, listening, and reading. Speaking and writing are two productive skills as they create product in form of sounds and writings. Meanwhile, listening and reading are unproductive skills on account of product receiving. To that reason, it is agreed that the most important skills are speaking and writing. But in the case of communication, speaking is the most essential one as it can directly create communication and transmit information without any supporting media as paper or typewriter in writing. However, having the ability to speak or inform something is not enough for communication. It requires good listening skill too since the concept of speaking is giving information and receiving it as exchanging results.

In Indonesia itself, study on listening are practiced from elementary school up to university with different levels according to education level they attend. It is obvious that the higher level of education they are in, the more difficult the material of listening they will have. Then it is agreed that on study English listening, students face some challenges especially for EFL students. Since English is treated as foreign language in Indonesia, the issues taken by Indonesian learner are seriously matter. Some challenges are in form of different accent, different phonetic alphabet, and pronunciation. These difficulties may relates listening to speaking as they complement each other. We learn that there are 3 kinds of major accent of English: British, American, and Australian which differ from Indonesian. Moreover, different phonetic alphabet between English and Indonesian occurs to make different pronunciation so that sometimes students find it difficult to identify the spoken words uttered in English due to the students' lack of understanding. Regarding to that reason, English as an important language in education is taught through some media which by some researches were believed effective. Along with the higher interest in English, some struggles are done by teachers in implementing teaching media especially in listening skill. Some selected media are audio and phonology course.

Some previous studies related to the implementation of learning media in listening course were conducted by researchers, such as: Carnaliaet.al. (2019), Munggaraning, S. (2019), and Dwi, et. al. (2015). Carnalia et al (2019) observed the effectiveness of letter sound training in improving initial reading skill in Grade 1 Elementary School students. For the further research, Carnalia, et al (2019) revealed that letter sound training is effective to improve initial reading ability of Elementary School students ofone SDN in Jakarta Barat. Next, another study investigated the implementation of phonic method in early reading of English for young learners (Munggaraning, S., 2019). The result of this research revealed that the implementation of phonic method help teachers to introduce the letter sound which is the first foundation in English initial reading course. Another research that conducted by Dwi, et al (2015) revealed the improvement of initial reading ability of Grade 1 students in Elementary School. This research discussed about the influence of phonemic awareness learning through 
Structural, Analysis, \& Synthesis (SAS) method toward initial reading ability increasing of Grade 1 students in Elementary school.

The above studies together discuss the use of media in teaching reading. The point of differences occurs in the media used in the research. Where research conducted by Carnalia et al (2019) intend in using letter sound training, while Munggaraning, S. (2019) conducted a study related to phonic method implementation and Dwi et al (2015) more attract on discussions about using SAS method in initial reading course.

Based on the research development above, which is still limited to use media in reading course. In this study the research puts audio and phonology learning in listening course. Furthermore, to create this research it is previously given phonology course and using online media before conducting the research. That is why, it is crucial to run that research to know the enhancing of ability in listening skill.

\section{LITERATURE REVIEW}

In linguistics there are subdisciplines which cope with sound, particularly phonetics and phonology. Phonetics affords goal approaches of describing and analyzing the variety of sounds people use of their languages even as phonology is the language unique choice and organization of sounds to sign meanings. Phonology is language unique that includes a reduction to important data to what speakers and listeners suppose they're pronouncing and hearing. According to Fraser (2006), phonology is the examination of the sounds of speech and the way they feature to assist us deliver which means in language.

The courting among phonetics and phonology is a complicated one however phonology is extra specific than phonetics. In phonology there is International Phonetic Alphabet (IPA), a standard transcription system for phonetic and phonology that used to put in writing down the unexpected sounds of different language. (Mahon, 2002)

Besides phonology has relationships to the others factors of grammar inclusive of phonology is tormented by morphology, morphology also can be tormented by phonology, phonology may be conditioned with the aid of using syntactic shape, however phrase order as a minimum in slender instances also can be tormented by phonology (Zuraw, 2007)

There are essential sorts of phonological process, they are complete section methods and change kind methods. Whole section methods are the ones methods that have an effect on the segmental shape of the phrase, with the aid of using deleting, placing or converting segments from one contrasting section to another. Types of methods which add, delete transfer or deliver upward push to new segments, there are methods which regulate segments in diverse approaches the change kind methods lead to the increase of allophones in the phonemic systemic system of a language. (Pandey, 2006)

Next, online media refers to applications of computer include multimedia, artificial intelligence, and networking (Meidasari, 2016). Online media or known as digital 


\section{Dwi Astuti Wahyu Nurhayati}

media is important part of education. It helps teacher and students advanced to conduct teaching and learning process as it uses technology, the Internet in practicing it. Internet, as a tool and platform is considered as the main key both for formal and informal education. And this leads digital media to be part of our lives and therefore becomes a key components of education (Chien, 2014). Online education itself is the form of education provided by entities, educational institutions, and companies through platforms based on online technologies. However, educators from both formal and informal school are demanding high-quality teaching and learning tools that exploit digital media (Scholz, 2010).Chien (2014) explained that online media and technology together are changing the developmental landscape for learners in the digital age of today and future.Then it is in line with listening teaching that students can get materials such as: videos, films, audio stories, and Edmodo from online media platform.

Then, listening is one of the four important skills in mastering English language. It helps students to conduct some academic activities such as lecturers, presentation, or speeches. Listening is the activity of paying attention to and try to get the meaning from the information that has been heard (Ardhani, 2012). Listening skill is the ability of a person to identify and understand what others are saying. In learning listening, there are 3 levels of listening: literal level, inferential level, critical level, and creative level (Al-Musalli, 2001). According to that statement, inferential level relates to the comprehension of the text includes: inferring the speakers' attitude, intention, thoughts, motivation, purpose, and implied ideas or details.

\section{RESEARCH METHODOLOGY}

This research used descriptive qualitative design. According to Vickie and Clinton (2012) qualitative descriptive is a feasible and proper label for a qualitative research design. Qualitative descriptive method desires to be the layout of desire when a uncomplicated description of a phenomenon is desired. The researcher used that approach due to the fact it's far appropriate to the targets of the studies which targeted on college students view in phonology and on line media utilized in improving inferential listening skill.

This study was performed at IAIN Tulungagung in the course of five months commenced from April to August 2020. The subject on this studies are known as informants. The informants of this studies are 196 the English students of third semester.

There has been device that utilized by the researcher, they are questionnaires and interview. The cause of dispensed questionnaires is to recognize the scholars' enjoy whilst studied through on line media. Questionnaires are beneficial for accumulating biographical records on speakers, and quantifiable facts on language abilities, practices, and attitudes (Codo, 2009). Then the researcher used guided interviews to get records from the students deeply. This interview is entire and designated listing of 
query so it's far established interview. Besides interview can fit the scholars'answer in questionnaires and directly.

The facts have been analyzed through qualitative facts evaluation on the premise of the studies questions. As mentioned in facts series section, there have been reassert of facts on these studies, the ones are the end result of dispensing questionnaires and accomplishing guided interviews.

The facts from interview are analyzed in three steps. First, the interviews have been transcribed into written form. Second, the transcribed have been given lower back to the respondents to test whether or not it has pondered what they supposed to offer facts for evaluation. Third, the transcripts have been condensed into briefer statements wherein the primary experience of what's stated is rephrased in some words. Finally, the facts could be percent and categorized with the aid of using the usage of facts evaluation in regards to the studies questions.

The evaluation changed into finished thru three components, namely: 1) facts reduction, 2) facts presentation, and 3) drawing conclusions and verification (Cresswell, 2009). Besides that, the studies extensively utilized coding system with 6 thing analyzes Spradley, 2006; Creswell, 2014; Santosa, 2017), namely (1) accumulating uncooked textual content facts, (2) dividing and organizing records segments, (3) analyzing all facts, presenting section codes or parts, and lowering the code or simplify the code, (4) converting the code into subject matters into 4 dimensions or subject matters of studies which includes their angle as on line person and feature distinct history knowledge, blessings and downsides the usage of on line learning, (five) connecting subject matters with concept and case studies, (6) deciphering the that means of the studies subject matters.

This research has been conducted for 5 months starting from April till August 2020. The place for conducting this research was in the IAIN Tulungagung campus. Then, the subjects in this research are called informants, the subject is taken from third semester English major students. The total number of informants were 196 students.

\section{FINDING}

\subsection{Students' Perspectives on the Importance of Online Learning English Media}

According to the questionnaire, it was gotten some students' perspective towards the important of online learning English media. The highest perspectives that have agreed by $28 \%$ students is that online learning English media could be used to gain information. Next, it was followed by $25 \%$ students who believed that online learning English media can make students learn independently. Then, Effective and efficient are considered one of many importance of online learning by $21 \%$ students. However, not all students agreed that learning English should be done through online media as stated by $5 \%$ students. In contrast, about $11 \%$ students chose online media because of the various features provided and $10 \%$ declared that online media can be used as learning sources. 


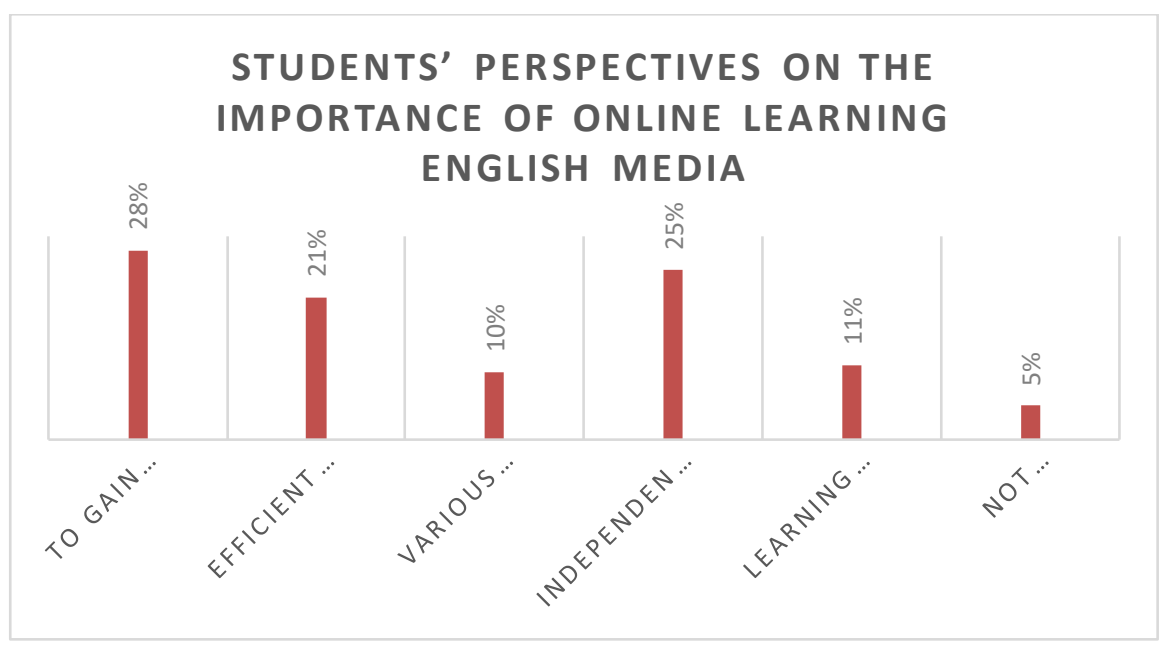

\subsection{Online Learning English Media towards students' attitudes in Learning (Critical, Advanced, Active)}

The questionnaire also showed the effect of online learning English media towards students' attitudes in learning in form of critical, advanced, and active.

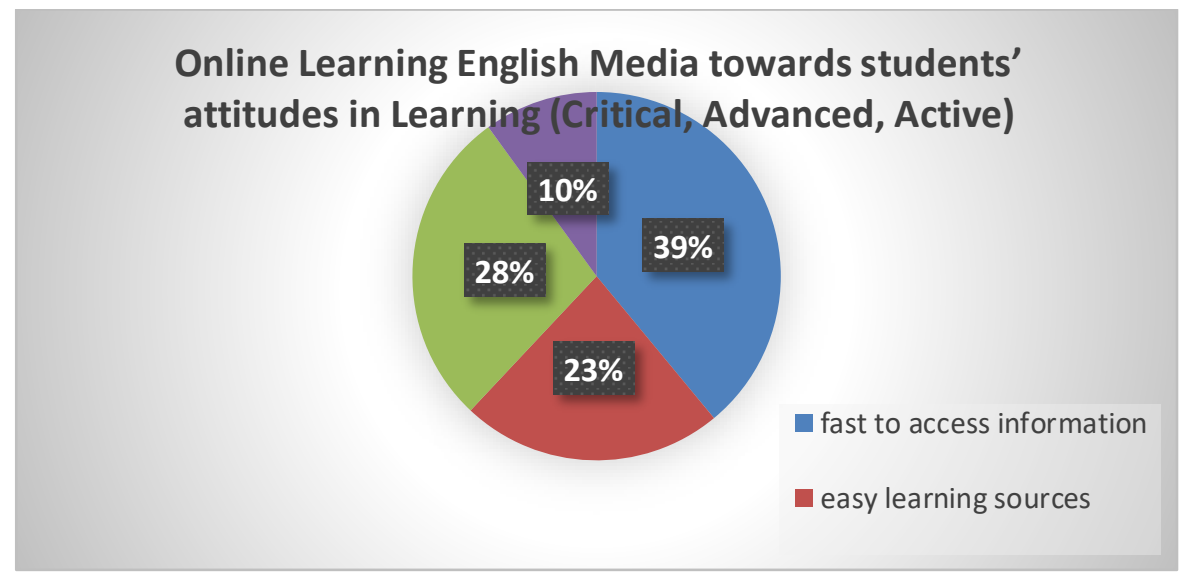

According to the diagram above, the result of the questionnaire presented that about $39 \%$ students agreed that learning English through online media affected their attitudes due to the fast access of information. Then, $28 \%$ students believed reading and learning English through online media could help them understand materials. In addition, online media make students easily gain learning sources as mentioned by $23 \%$ students while the rest about $10 \%$ students delivered that online learning English media had no specific effect towards their attitudes in learning.

\subsection{Students Perspectives on the Effect of Online Learning English Media towards Inferential Listening}

Besides perspectives on the important and attitudes, the result of questionnaire also presented some effects of online learning English media toward their English skills and comprehension (pronunciation, vocabularies, grammar, fluency, and comprehension). 
It was gotten that about $24 \%$ students declared that online learning English media affected their ability in pronunciation followed by $21 \%$ students agreed on fluency increasing. Then, vocabularies were also affected because of learning English through online media as stated by $20 \%$ students. Otherwise, comprehension and grammar were declared being affected according to $17 \%$ and $12 \%$ students while $6 \%$ students believed that learning English through online media has no specific effect toward their skills and comprehension.

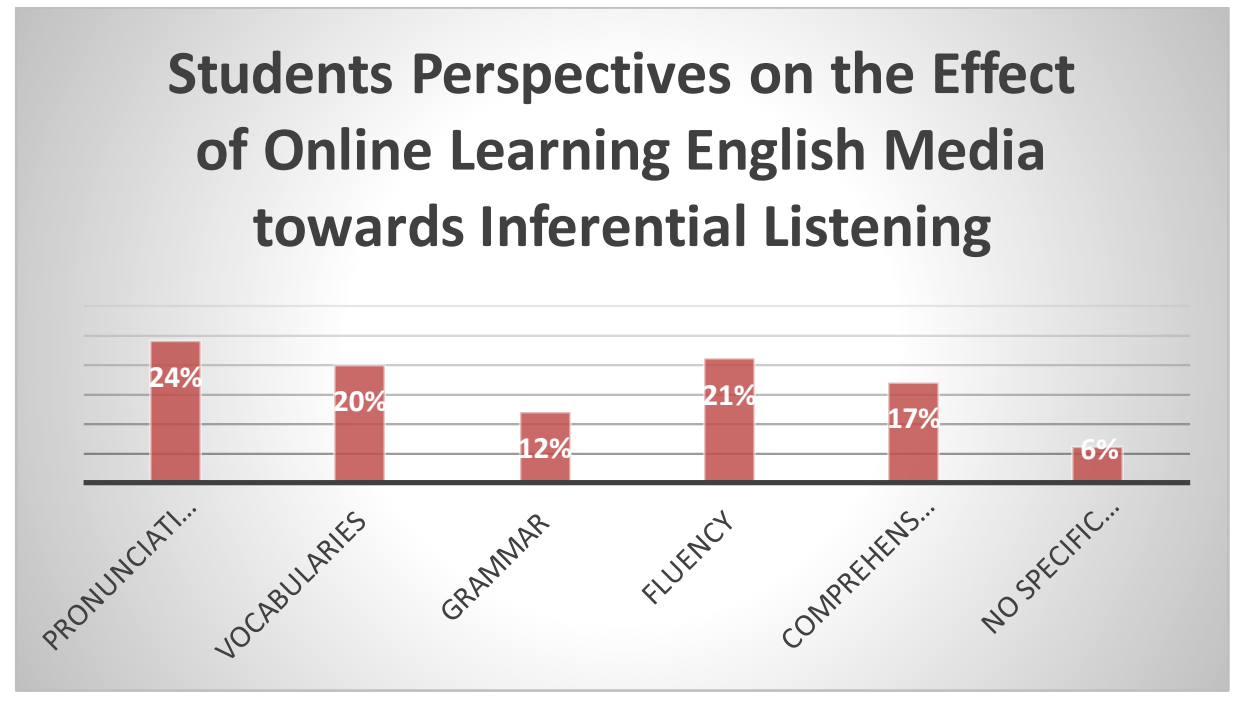

\subsection{Students Perspectives on Media Enhancing Inferential Listening Skill}

From the questionnaire, there were some students' perspectives on media enhancing inferential listening skill such as: Edmodo, film, audio stories, video, and creating modules.

\section{Students Perspectives on Media Enhancing Inferential Listening Skill}

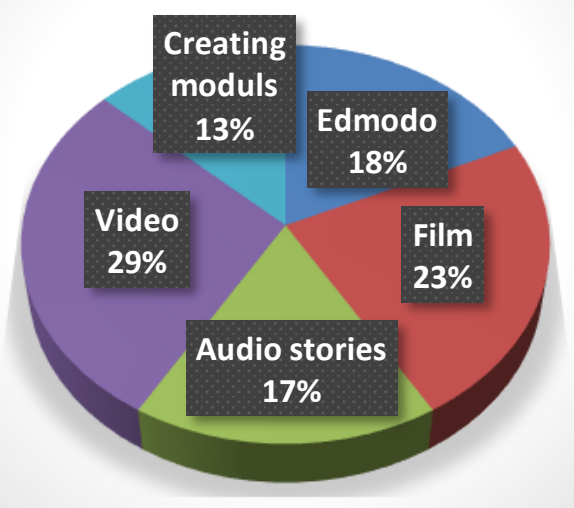


From the diagram above, it can be seen that the most used media in enhancing inferential listening is video. It was agreed by about $29 \%$ students. Then, it was followed by $23 \%$ students chose film as media to enhance their inferential listening skill. In addition, Edmodo which delivered once a week also believed by $18 \%$ students to be the used media while another media as in audio stories was supported by $17 \%$ students. Furthermore, not only media provided by teacher or the Internet, creating modules by students themselves are also considered can enhance students' skill in inferential listening as stated by $13 \%$ students.

\subsection{Students responses on Phonology in Enhancing Inferential Listening Skill}

Besides online media, phonology has important role in learning inferential listening. Since phonology allow us to understand sounds, it is agreed that phonology support students in advancing their skill in inferential listening. As stated by Anisaul that understanding phonology makes them understand native speakers easily.

In my opinion, the use and comprehension of English phonology theory in listening study is about 95\% important because if they understand the theory, they will easily catch what native speakers saying. Not only that, by understanding English phonology theory, students can differentiate kinds of sound due to the various sounds existed in English as in words cheek and chick in which the vowel /i/ in word chick is shorter while vowel /i:/ in cheek is longer. According to that condition, understanding English phonology is expected can make student more understand in differentiating certain words in listening. Furthermore, students are also gain advantage as they can pronounce certain words easily and fluently. (Anisaul)

In addition, Marzuqoh also explained the same concept that Phonology is important to listening according to the fact that it help students to listen better.

I agree with the statement that Phonology helps us in understanding spoken words uttered by native or nonnative speakers. In my point of view, phonology gives us acknowledgement about various sounds available in English and how the right sound it should create. So that, by listening phonology, indirectly we can absorb words better. (Marzuqoh)

\section{DISCUSSION}

From the result, firstly it can be seen some students' perspectives on the important of online learning English media. The most reason to the importance that online media gives students information stated by $28 \%$ students, creates independent learning agreed by $25 \%$ students, efficient and effective declared by $21 \%$ students, and $11 \%$ students chose online media as learning source. The concept online media gives information is in line with study conducted by Baruah (2012) that showed users of online media can search for information, use and download the content provided by the online media sites freely. This statement also occurs to learning in which students can also search the content they require as well as use and download it. In further, students can learn independently as a result of the easy way in collecting material to study. This is also 
similar as study mentioned by Sudarwati and Rukminingsih (2018) that the usage of learning through online is helpful to improve the process of learning quality in higher education. As a result, students can search and determine their own learning source and strategy. Besides, the effectiveness and efficiency available in online media make students opt online media to learn. Baruah (2012) on a study explained that low cost and effectiveness make students pay a less certain amount of money or in other word it is cheaper.

Then, the second analysis of the study shows the role of online learning English media towards students' attitudes in learning in form of critical, advanced, and active learning. The result presented 39\% students agree due to the fast access of information while $28 \%$ students believed that reading and search information from online media makes them understand the material. Then, $23 \%$ students stated that online media is easy learning source. On the other hand about $10 \%$ students believed there is no specific effect of online media toward critical, advanced, and active learning. According to result above, the content accessed through online media is considered fast, easy, and understandable. It allows students to search various information with less time consuming. This is for sure as the result of technology development collaboration with learning. As suggested by SuhHeejeon (2011) that a collaborative learning model as well as classroom environment and support technologies was suggested in order to create good future classroom. Today learning is not only face-toface that it needs virtual learning as well as a combination form of learning.

Furthermore, the study also explained students' perspectives on the effect of online learning English media towards students' skill and comprehension. About 24\% students agreed that their pronunciation were affected by learning through online media, $21 \%$ students believed in fluency increasing, and $20 \%$ students declared that their vocabularies increased as the result of learning through online media. Meanwhile, comprehension and grammar are agreed affected by $17 \%$ and $12 \%$ successively. This is in line with Bulut and Karasakaloglu (2012) who stated that the achievement of students' listening comprehension contributed to learning new words. According to that statement, it is related that listening can affect students' vocabularies. By listening, students can absorb new words uttered during listening process although it may need twice or more repeating. Not only that, grammar that is considered has no relation with listening, apparently it has connection. According to Hagen (2012), one of most meaningful and efficient ways to increase understanding is to provide listening instruction at the time students are learning certain structure. It informs that although written language is more ordered than spoken language, listening still affects grammar comprehension.

In addition, the perspectives on media enhancing inferential listening skill are also explained. The result of study presented that video is agreed by $29 \%$ students as media to enhance listening skill followed by film chose by $23 \%$ students, Edmodo by $18 \%$ students, audio stories by $17 \%$ students, and creating modules by $13 \%$ students. The results above are suitable with Mohamed (2018) who explained that audiobook or 


\section{Dwi Astuti Wahyu Nurhayati}

audio stories were useful in increasing students' listening skill. Through audio stories, students can listen and analyze what being spoken by native or nonnative speakers so that they can get understanding by the process. Not only audiobooks, movies are useful as well towards listening as mentioned by Adnan (2014) that many advantages gained by watching movies such as correct pronunciation and expression. By watching movies, students can learn pronunciation and expression uttered by the characters correctly as they are taken to the real context of situation of movies. Edmodo as one of some learning media also contributes to listening skill. The use of Edmodo help students to get material suitable with what being taught in school. As explained by Siahaan (2020) that the use of Edmodo can improve students' language skill as in developing interaction and communication. These interaction and communication skills include listening since communication gives and asks for information.

Additionally, the result also showed students responses on Phonology in enhancing listening skill. From the interview it can be seen that the use of phonology help students to understand more pronunciation, spelling, stress to help their listening skill. By phonology they can differentiate sounds since English has various different sounds. This is in line with study conducted by Purnama et al (2019) about listening phonological errors that they suggested students should study the phonological system in the target language as well as guide students' pronunciation in order to create good communication. So that to make good conversation, students need to understand phonology system as it allows them to listen and speak correctly.

\section{CONCLUSION}

This study aims to understand phonology and online media used to enhance inferential listening skill. From the result of this study, the researcher concluded that students agree to the important of online media as it gives many content and information, effective, efficient, and can be used as learning source. Then it was also beneficial to students' learning due to the fast access of information and less time consuming. Some ability and comprehension are affected and increased during listening practice such as: pronunciation, grammar, fluency, and vocabularies. However, in learning listening, it can be concluded some media to be used in increasing listening ability: video, films, edmodo, audio stories, and modules. The study proved that phonology is also beneficial to listening that it makes students able to acknowledge various sounds and differentiate them.

\section{REFERENCES}

Adnan, Aryuliva. (2014). Improving Students' Listening Ability through Movie Report. SELT Padang June 11-12.

Al-Musalli, Alaa. (2001). Listening Comprehension as a Complex Skill and the SubSkills Involved in the Process of Speech Perception. 35-84. 
Ardhani, R. A. V. K. (2012). Challenging Issues in Learning: A Correlational Study in University Level. Journal of Engliah and Education, 6(2), 103-111.

Baruah, Trisha D. (2012). Effectiveness of Social Media as a tool of communication and its potential for technology enabled connections: A micro-level study. International Journal of Scientific and Research Publication, 2(5), 1-10.

Bulut, Beker and Karasakaloglu, Nuri. (2017). Benefiting from Listening in Vocabulary Development. Journal of Education and Training Studies, 5(12), 99109.

Carnalia, B. S., Tiatri, S., and Patmonodewo, S. (2019). EfektivitasPelatihanBunyiHurufdalamMeningkatkanKemampuanMembacaAwal Siswa SD. JurnalMuaraIlmuSosial, Humaniora, danSeni, 3(2), 440-448.

Chien, Ming-tso J. (2014). How Digital Media and Internet Transforming Education. Research Gate, 1-10.

Codo, E. (2009). The Blackwell Guide to Research Methods in Bilingualism and Multilingualism (pp.158 - 176).

Cresswell,J.W.(2009).Research Design:Qualitative,Quantitative,and Mixed Methods Approaches.LosAngeles:Sage Publications.

Cresswell,J.W.(2014).Research Design:Qualitative,Quantitative,and Mixed Methods Approaches.LosAngeles:Sage Publications.

Dwi, S. R., Primastuti, E., and Tanti, C. U. (2015). Pembelajaran Kesadaran Fonemik dengan Menggunakan Metode Struktur Analisis Sintesis (SAS) untuk Meningkatkan Kemampuan Membaca Permulaan Siswa Kelas 1 SD. Prediksi, Kajian Ilmiah Psikologi, 4(1), 81-91.

Fraser, H. (2006). Phonological concepts and concept formation: metatheory, theory, and application. Internation journal of english studies. Vol. 6 (2), pp.55-75.

Hagen, Stacy. (2012). The Grammar-Listening Connection: An Interview with Stacy Hagen. Pearson Education, Inc.

Mahon, A. (2002). An introduction to English Phonology. Edinburgh University press.

Meidasari, V. E. (2016). The Using of Digital Media to Enhance Teaching and Learning English on the Well-being of Indonesian Students. Journal of English Language and Culture, 6(1), 76-86.

Miles, M. B., and Huberman,A.M.(1994).Qualitative data analysis:an expanded sourcebook(2nded.).London:Sage.

Mohamed Manal K. M. (2018). Using Audiobooks for Developing Listening Comprehension among Saudi EFL Preparatory Year Students. Journal of Language Teaching and Research, 9(1), 64-73.

Munggaraning, Sharina W.

W. (2019). MetodeFonikdalamPembelajaranMembacaPermulaanBahasaInggrisAnakUsiaDi ni. Jurnal Tunas Siliwangi, 5(1), 23-37.

Newby,T.J.,Stepich,D.A.,Lehman,J.D.,\&Russel,J.D.(2006).Educational technology for teaching and learning( $3^{\text {rd }}$ ed.).UpeerSaddleRiver,NewJersaye:Merril/Prenticehall. 
Pandey, P. (2006). Types of phonological pricesses-1. Centre for linguistics, SLL \& CS Jawaharlal Nehru University, New Delhi.

Purnama, S., Farikah, Purwanto, B, K., Wardhani, S., Kholid, I., Huda, S., \&Joemsittiprasert, W. (2019). The Impact of Listening Phonological Errors on Speaking: A Case Study on English Education. Journal for the Education of Gifted Young Scientist, 7(4), 899-913.

Santosa,R.(2017).Metodepenelitiankualitatifkebahasaan.Surakarta:UNS Press.

Scholz, R. Trebor. (2010). Learning Through Digital Media: Experiments in Technology and Pedagogy. The Institute for Distributed Creativity: New York.

Siahaan, Erna B. (2020). Students' Perception of Edmodo Use as a Learning Tool. Journal of English Teaching, 6(1), 12-23.

Spradley,J.P.(2006).Metodeetnografi(Ethnograpic methods) (M.Z.ElizabethTrans). Yogyakarta:TiaraWacana.

Sudarwati, Ninik. (2018). Evaluating E-Learning as a Learning Media: A Case of Enterpreneurship E-Learning using Schoology as Media. i-JET, 13(9), 269-279.

Suh, Heejeon. (2011). Collaborative Learning Models and Support Technologies in the Future Classroom. International Journal for Education Media and Technology, $5(1), 50-61$.

Vickie, A and Clinton, E. (2012). Qualitative descriptive research: an acceptable design. Journal of nursing research. Vol.16 No.4

Zuraw, K. (2007). Introduction to phonology. UCLA Department of linguistics. 